\title{
Effective Teaching and Activities of Excellent Teachers for the Sustainable Development of Higher Design Education
}

\author{
Yi-Chen Lai ${ }^{1,2}$ and Li-Hsun Peng ${ }^{3, *(1)}$ \\ 1 Graduate School of Design, National Yunlin University of Science and Technology, Douliu 64002, Taiwan; \\ D10230019@gemail.yuntech.edu.tw \\ 2 Department of Multimedia and Animation, Tainan University of Technology, Tainan 71002, Taiwan \\ 3 Department of Creative Design, National Yunlin University of Science and Technology, Douliu 64002, Taiwan \\ * Correspondence: penglh@gemail.yuntech.edu.tw
}

Received: 21 November 2019; Accepted: 15 December 2019; Published: 18 December 2019

\begin{abstract}
Education for sustainable development (ESD) is regarded as a key element of high-quality education. Hence, the United Nations proposed the Sustainable Development Goals (SDGs) in 2015, in an attempt to achieve the harmony and shared prosperity between humans and the Earth, and advocate for fair and high-quality education. With the aim of exploring "high-quality sustainable teaching", this study intends to probe into the idea and meaning of the high-quality design education for sustainable development and elaborate on the teaching effectiveness and sustainable teaching activities by the teachers of higher design education. According to the research results, the effectiveness of high-quality teaching is introduced in seven categories, as follows: (1) Faith in sustainability in teaching, (2) the trend of talent demand, (3) the teaching value of sustainability, (4) curriculum mapping, (5) teaching approach, (6) teaching evaluation, (7) the sustainable management of teaching development. The factors of high-quality teaching include: The teacher has passion for teaching, the teacher pays attention to the student's independent learning ability, the teacher intrigues student's interest in learning, the teacher places emphasis on furnishing the student with professionalism and confidence, the teacher highlights learning through doing to increase the student's competitiveness in the job fair, the teacher reviews teaching effectiveness and makes progress in pursuing the value of high-quality ESD.
\end{abstract}

Keywords: education for sustainable development (ESD); higher education; design education; teaching effectiveness

\section{Introduction}

The future is determined by us, thus, we must ensure that our behaviors will be favorable for future generations and that they will not suffer the consequences of our mistakes [1]. The United Nations Education Scientific and Cultural Organization (UNESCO) has been promoting Education for Sustainable Development (ESD) since 1992. From 2005 to 2014, it directed the development of the United Nations (UN) ESD and is implementing the Global Action Program (GAP) for Education for Sustainable Development. Thus, new skills, values, and attitudes are needed to fulfill this objective [2]. The Decade of the United Nations Education for Sustainable Development (2005-2014) invested all resources to create a sustainable future. There are many ways to achieve sustainable development, and education is one of them [3]. In addition, the Global Action Program (GAP) for Education for Sustainable Development is a follow-up program of the Decade of the United Nations Education for Sustainable Development (2005-2014), which is designed to speed up the spread of Education for 
Sustainable Development. GAP is the most important pillar for UNESCO to support the 2030 Agenda for Sustainable Development and has two goals: (1) To reset education and learning, in order that everyone will have access to knowledge, skills, values, and attitudes, and thus, make contributions to a sustainable future, (2) to improve education and learning in all agendas (i.e., other SDGs) and schemes to publicize sustainable development [4]. The UNDESD advocates incorporating Education for Sustainable Development into educational policies, and while it offers relevant suggestions and guidelines, it is not a mandatory rule for all. Hence, there are some difficulties and challenges in putting it into practice [5-7].

In summary, this study aims to understand the importance of sustainable education. Education is not only to impart knowledge and guide the development of personal careers but also to guide the hope of our advancement. "Design" is representative of creativity and aesthetics. In the current environment, people realize that "design is a national strength" and "creativity is competitiveness" [8]. Due to industrial demands and the influence of government policies, the number of higher education schools equipped with design-related departments in Taiwan is increasing year by year. Therefore, design education has become a vigorous eye-catching research area [9]. Higher education institutions (HEIs) continuously strive to develop and deliver impactful educational programs, thus, they perform periodical curricular reviews adhering to internal and external quality assurance systems [10]. While there has been a great deal of publicity, and ESD in higher education has been effective, discussions on sustainable teaching approaches for design education are rare [11].

Therefore, this study aims to explore "sustainable teaching", which aims to understand the sustainable development of higher design education, explores effective and sustainable teaching activities for high-quality design education teachers, and expects to enhance the teaching of higher design education. Quality and student learning outcomes are as follows.

Based on the above argument, this study aims to (see Figure 1):

1. Adopt qualitative research methods, as well as in-depth interviews with excellent teachers of higher design education to understand the relevant factors and connotations of teaching excellence;

2. Analyze the high-quality elements of higher design education for sustainable development;

3. Incorporate the interview results into the fuzzy Delphi method (FDM) for the expert questionnaire;

4. Invite the teachers of higher design education to complete a questionnaire and use the FDM in the statistical analysis and combine with expert opinions to obtain agreement.

5. Understand the relationship between sustainable development education and design education and understand the connotations of ESD through the discussion of quality teaching concepts.

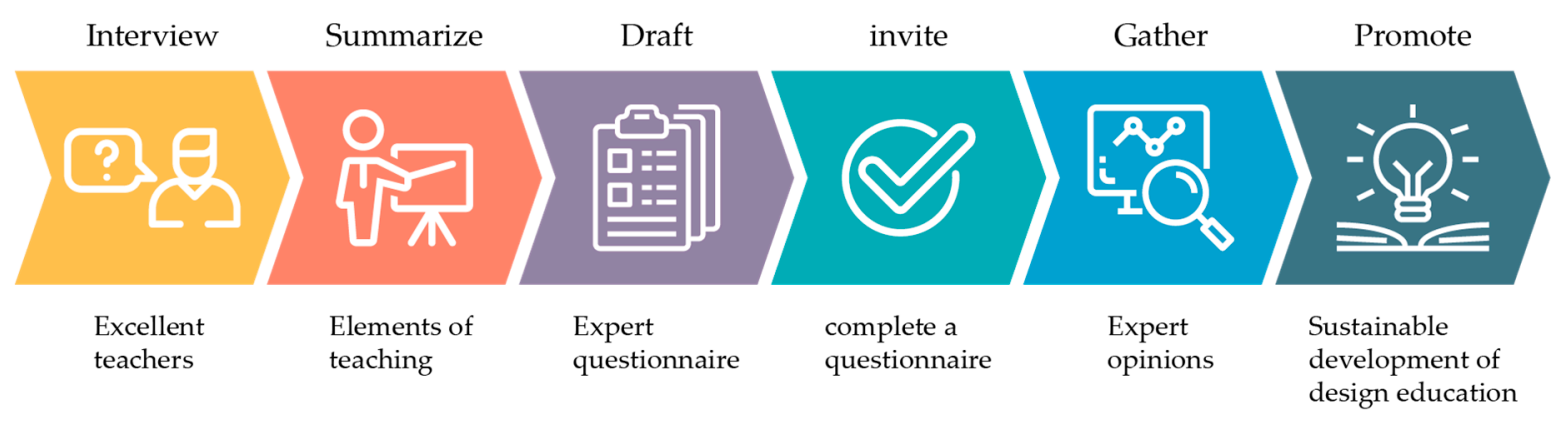

Figure 1. Procedure for the research on the higher design education for sustainable development (plotted for this study).

\section{Literature Review}

\subsection{Education for Sustainable Development (ESD) and Teaching Effectiveness}

The Earth has limited natural resources, thus, people and nature should be in harmony and pursue sustainable development. For that reason, the sustainable development of the environment 
has become an essential topic that catches global attention. Education, in fact, plays a pivotal role in sustainable development [12], and sustainability is one of the important strategies of the United Nations. In the field of education, we must work towards inclusive and equitable quality in education, provide lifelong learning opportunities for many, and establish effective learning environments [13]. UNESCO is committed to spreading education, which is a basic human right, as well as an important tool for us to attain sustainable development $[14,15]$. ESD can lead schools toward greater excellence and change peoples' minds so that they would endeavor to create a wonderful society [16]. Given the development trend of modern higher education, improving education for its sustainable development has become an emerging research field, and students are expected to practice and accelerate sustainable development [7,17-20]. ESD contributes to changes to educational models, such as interdisciplinary and creative teaching, what is taught, learning by doing, and teaching effectiveness, and aims to achieve sustainable development through educational practices [14]. Wals interpreted the elements of sustainable development ability and the German term "Gestaltungskompetenz". According to Wals, the elements of sustainable development include: Foreseeing methods for predicting an uncertain future, plan implementation, interdisciplinary thinking, teamwork, empathy, self-motivation, review, interaction between sustainable development and "Gestalts" [7,21]. Teaching was defined as imparting knowledge to or instructing (someone) how to do something: Give information about or instruction in (a subject or skill) [22]. This study defines effective teaching as that which leads to improved student achievement using outcomes that matter to their future success. It is not easy to define teaching effectiveness, and the key is that student progress is the yardstick by which teacher quality should be assessed [23]. As higher education can train talents and push forward social development, many countries have been trying to make investments in education to improve it. A discussion on teaching effectiveness is essential because it has an influence on students' learning effectiveness. Additionally, "twelve potential sources of evidence of teaching effectiveness" have been identified: (1) Student ratings (such as student evaluations of teaching), (2) peer reviews, (3) self-reviews, (4) videos of practice, (5) interviews with students, (6) alumni, employers, and administrator ratings, (7) teaching awards and scholarships, (8) learning outcome measures, and (9) maintenance of teaching portfolios [24]. According to the Cone of Learning (Figure 2), learning can be divided into active and passive learning, and different learning methods would lead to different learning effectiveness. Taking the after-learning retention rate as an example, the retention rate of learning by doing is $10 \%$, that of learning by listening is $20 \%$, that of learning with pictures is $30 \%$, that of learning with videos, exhibitions, demonstrations, and on-site observations is $50 \%$, that of learning by discussing, raising questions, and making speeches is $70 \%$, that of learning through presentation, teaching, simulated experience, and practice is $90 \%$ [25]. As shown in Figure 2, the traditional learning methods with learning effectiveness of less than $30 \%$ are all individual or passive learning modes, while the learning approaches with learning effectiveness of over $50 \%$ are group, active, and participatory learning. Given that the "different learning approaches would lead to different learning effectiveness" in the Cone of Learning, teachers should adjust methods and roles in teaching, give students a dominant position in learning, guide students to simultaneously participate in cooperative learning, increase the effectiveness of teaching and learning, and fulfill the educational objective of sustainable development. 


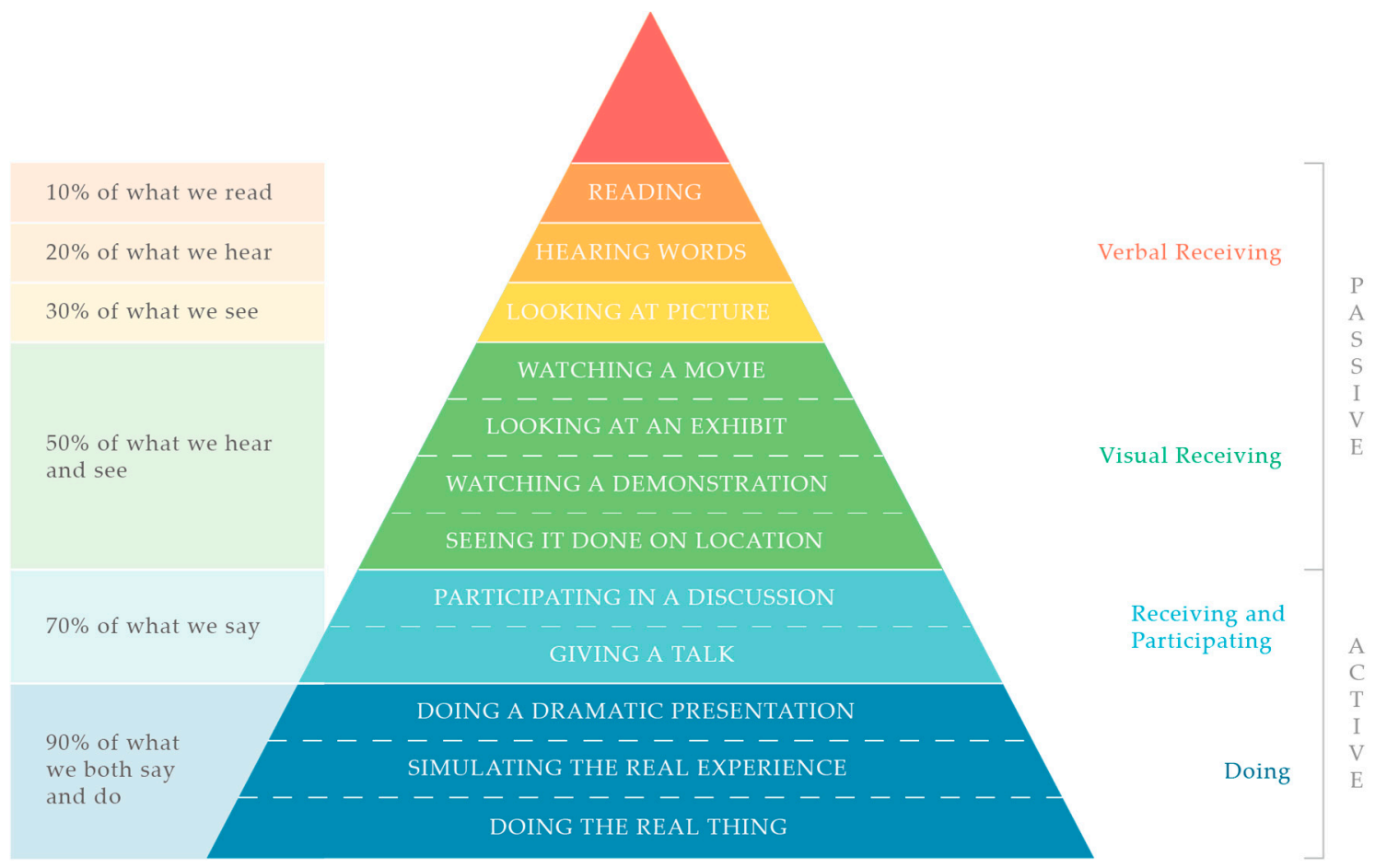

Figure 2. Cone of Learning. Source: Dale, E. Audio-visual methods in teaching; Holt, Rinehart and Winston: New York, NY, USA, 1998.

\subsection{Higher Education and Design Education}

HEIs aim to build a society of sustainable development and contribute to the world through education, research, and publicity [26,27]. "Humans" are the core of sustainable development, and human quality is the key to sustainable development. According to the abovementioned, education is important for sustainable development, and only by putting the idea of sustainable development into practice in education will we be able to realize the objective, achieving sustainable development in the global society. With the aim of training elite and professional people for future society, higher education has an influence that cannot be neglected during the development direction of society. Therefore, it is necessary to incorporate the idea of sustainable development into higher education when humans are confronted with serious environmental problems [28]. The European Union University Social Responsibility (EU-USR) concept defines the social responsibilities of universities as obligated to adopt transparent strategies and measures to create positive impacts on society and the environment, promote social well-being, and pursue sustainable development [29]. "Design and creativity" have the power to change the world, as they can improve life, advance economic transformation, and solve many social problems, such as aging, environmental pollution, and poverty, and contribute to a better life for the global society [30]. Hence, higher design education is a force that should not be ignored in sustainable development. According to different perspectives, it is necessary for HEIs to integrate the idea of sustainable development with the educational system, and they have become increasingly experienced in doing so. However, it was found in the literature review that studies on how to combine the idea of sustainable development with higher design education are few [31,32]. Therefore, this study explores the teaching effectiveness of teachers in higher design education for sustainable development, in order to improve the teaching of sustainable development and motivate teachers to make self-improvements in teaching. 


\section{Results}

Following the principle of "efficient teaching", this study employs qualitative and quantitative methods to discuss strategies for the efficient teaching of higher design education, offers reference information for teaching improvements, and pursues the core value of sustainable development.

\subsection{Research Process and Academic Ethics Integrity}

Regarding the ethical integrity of this research, the researchers were certified and trained at the Center for Taiwan Academic Research Ethics Education (AREE, founded in 2014) [33] and followed the policy of the Ministry of Science and Technology on enhancing the knowledge and competency of Higher Education in Taiwan. Before the expert survey, the researchers obtained oral consent from the experts and recorded their consent.

This study has carefully followed the guidelines according to the spirit and Declaration of Helsinki as following:

Respect for the individual (Article 8), Respect their right to self-determination and the right to make informed decisions. Regarding participation in research, both initially and during the course of the research (Articles 20-22). The investigators' duty is solely to the volunteers (Articles 16, 18), and while there is always a need for research (Article 6), the subject's welfare must always take precedence over the interests of science and society (Article 5), and ethical considerations must always take precedence over laws and regulations (Article 9) [34].

Nowadays, AREE is the most important platform of Academic Ethics and Research Integrity in Taiwan [35].

This study is divided into three phases (see Figure 3):

Phase 1:

In-depth interviews were conducted on the topic of "effective teaching activities". When drafting the interview outline according to the abovementioned key issues, this study adopted purposeful sampling and semi-structured expert interviews to explore their perspectives on a particular idea, program, or situation [36]. Excellent teachers of higher design education were chosen as the interviewees to explore the "elements and meaning of high-quality teaching". The interviews contained the following five dimensions: (1) Teaching faith, (2) observations of social development and talent demands, (3) preparation for teaching, (4) the teaching-learning interactions, and (5) after-teaching review of excellent teachers of higher design education.

Phase 2:

In order to gather expert opinions, reach a consensus, and establish a standard framework of higher design education for sustainable development, this study prepared the items of the expert questionnaire according to the elements of "Effective Teaching and Activities of Excellent Teachers for the Sustainable Development of Higher Design Education", as based on the results of the expert interviews. In addition, Taiwanese teachers of higher design education were invited to complete the questionnaire, and the fuzzy Delphi method was utilized for statistical analysis, which was combined with the expert opinions to obtain agreement [37].

The Delphi method was developed by Rand in the 1950s and is a process where an expert team conducts an investigation to obtain group opinions or decisions [38]. The traditional Delphi method was combined with the fuzzy set theory to address some of the ambiguity of the Delphi panel consensus, which utilizes triangulation statistics to determine the distance between the levels of consensus within the expert panel [39-41]. The fuzzy Delphi method can be used as a tool to evaluate standard selections and has the following strengths, as compared with the traditional Delphi method: (1) Reduces the frequency of investigation to reach an expert consensus earlier, (2) offers a complete description of the opinions of all experts, (3) the fuzzy theory renders expert knowledge more rational and consistent with demands, (4) simplifies computation methods and makes time and cost more economically 
profitable [37,40]. Therefore, this study first adopted the qualitative interview method to collect data, and then utilized the fuzzy Delphi method to analyze the data to demonstrate the research findings, so as to enhance the validity and reliability of this research.

A Likert five-point scale was used for measurement, ranging from 1 (strongly disagree) to 5 (strongly agree). Based on the results, the semantic variables were converted into triangular fuzzy numbers to obtain the opinions of the scholars and experts. The conversion details are shown in Table $1[37,41]$.

Table 1. Triangular fuzzy numbers of the five-point Likert scale.

\begin{tabular}{ccccc}
\hline Strongly Disagree & Disagree & Neutral & Agree & Strongly Agree \\
\hline$(0.1,0.1,0.3)$ & $(0.1,0.3,0.5)$ & $(0.3,0.5,0.7)$ & $(0.5,0.7,0.9)$ & $(0.7,0.9,0.9)$ \\
\hline
\end{tabular}

Source: Shao-xun Zhang. Fuzzy Multi-Criteria Decision Making for Evaluation Method; Wu-Nan Book: Taipei, Taiwan, 2012.

Based on the contents and results of the interviews, the researchers developed the items of the scale, and used the fuzzy Delphi method for statistical analysis, to reach a consensus among the experts and remove the inappropriate items, so as to demonstrate the inferences with data. Microsoft Office Excel was utilized for the data analysis.

The fuzzy Delphi method comprises the following four steps: (1) Establish a fuzzy positive reciprocal matrix $\left[\widetilde{a}_{\mathrm{ij}}\right],(2)$ obtain the triangular fuzzy numbers regarding the importance of the standards $\widetilde{\mathrm{w}}_{\mathrm{k}}$, (3) defuzzy (DF), (4) select the evaluation indices [37].

(1). Establish a fuzzy positive reciprocal matrix $\left[\widetilde{\mathrm{a}}_{\mathrm{ij}}\right]$ :

The in-depth interview method in Phase 1 was used to collect the opinions of the experts, and then, the opinions were made into a questionnaire. The semantic variables in the questionnaires were utilized to obtain each expert's score to weigh the importance of the optional factors.

(2). Obtain the triangular fuzzy numbers regarding the importance of the standards $\left(\widetilde{w}_{\mathrm{k}}\right)$;

The experts' evaluation of the triangular fuzzy number of each standard was calculated to obtain the triangular fuzzy number regarding the importance of the optional factors $\left(\widetilde{\mathrm{w}}_{\mathrm{k}}\right)$.

Suppose that the importance evaluation value of the " $\mathrm{j}$ " initial index by " $\mathrm{i}$ " expert is $\widetilde{W}_{i j}=\left(a_{i j}, b_{i j}\right.$, $\left.c_{i j}\right), \mathrm{i}=1,2, \ldots, \mathrm{m}$, then, the fuzzy weight $\left(\widetilde{W}_{j}\right)$ of the " $\mathrm{j}$ " initial index can be obtained through the following equation:

$$
\widetilde{W}_{j}=\left(a_{j}, b_{j}, c_{j}\right), \mathrm{j}=1,2, \ldots, \mathrm{n} .
$$

In this equation,

$$
a_{j}=\operatorname{Min}_{j}\left\{a_{i j}\right\}, a_{j}=\sqrt[m]{\prod_{i}^{m} b_{i j}}, c_{j}=\operatorname{Max}_{j}\left\{c_{i j}\right\}
$$

\section{(3). Defuzzy (DF)}

The center-of-gravity (COG) is employed to defuzzy the fuzzy weight $\left(\widetilde{W}_{J}\right)$ of each optional element into a crisp value $\left(S_{j}\right)$, as expressed in the following equation:

$$
s_{j}=\frac{\left(a_{j}+b_{j}+c_{j}\right)}{3}, j=1,2, \ldots, m
$$

(4). Select the evaluation indices:

In the final step, the set threshold ( $\beta$ ) (as determined by the ascent method) is used to select an appropriate factor from a large number of factors, and the selection principles are as follows: Situation 
1: If $s_{j} \geqq \beta$, the " $\mathrm{j}$ " factor will be the evaluation index, Situation 2: If $s_{j}<\beta$, the " $\mathrm{j}$ " factor will be removed [37].

\section{Phase 3:}

The indices of effective teaching for higher design education were analyzed and induced according to the research results for the following purposes: Understand the meaning and core value of the sustainable development of design education, trigger the creative thinking of teachers, offer information to teachers to obtain feedback regarding their teaching, and then, make improvements, generate better teaching for sustainable development.

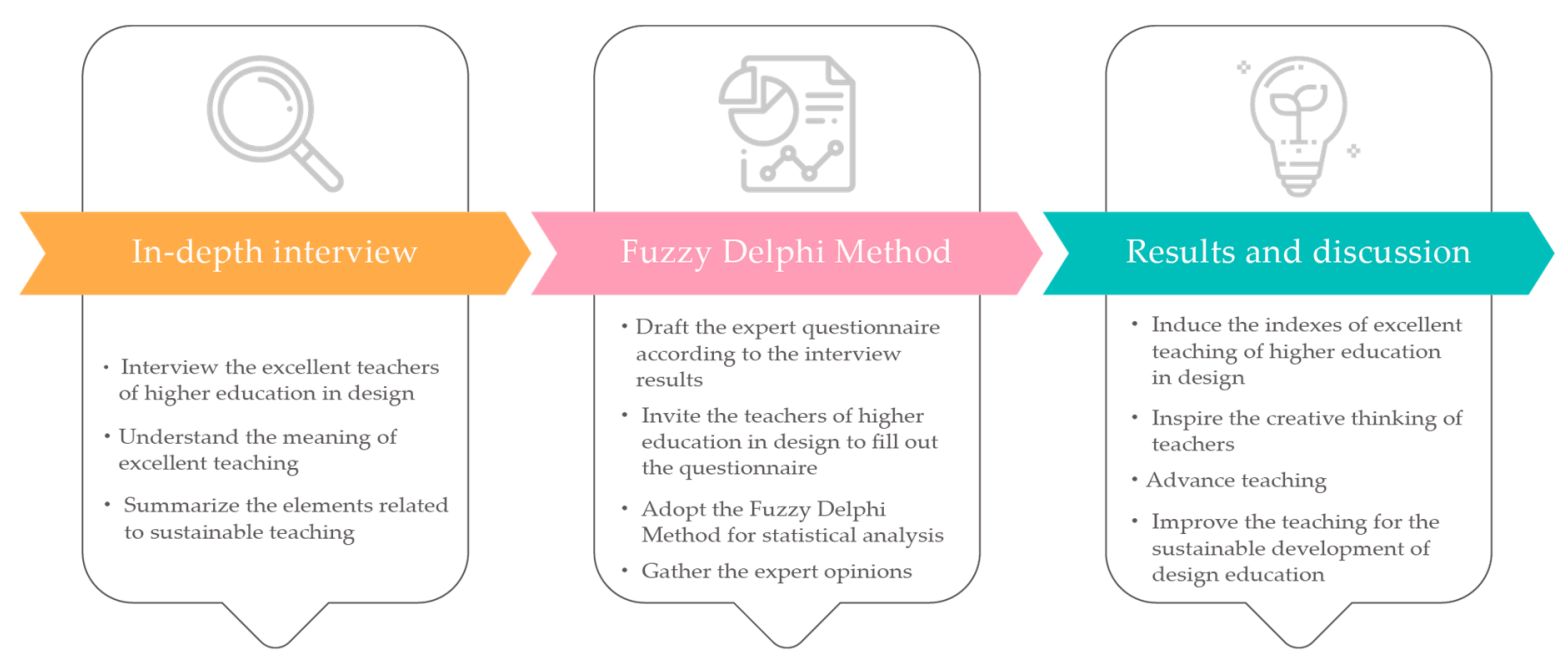

Figure 3. Research procedure (sustainable development of higher design education, plotted for this study).

\subsection{Research Samples and Subjects}

For the first step, this study conducted expert interviews with seven excellent teachers in higher design education, who had eight years of experience in the field. The criteria for excellent teachers included (1) received awards in excellent teaching on and off campus and (2) recommended by the deans of their schools or the directors of their departments and had at least 18 years of services on average. The basic information of the experts is shown in Table 2.

Table 2. Basic information about the interviewed experts.

\begin{tabular}{cccc}
\hline Interviewee & Department & Position & Years of Service \\
\hline T1 & Department of Industrial Design & Professor & 35 \\
T2 & Department of Creative Design & Professor & 15 \\
T3 & Department of Visual Design & Associate Professor & 20 \\
T4 & Department of Interior Design & Associate Professor & 27 \\
T5 & Department of Fashion Design & Associate Professor & 8 \\
T6 & Department of Cultural and & Assistant Professor & 12 \\
T7 & Department of Modern Living & Assistant Professor & 10 \\
\hline
\end{tabular}

In this study, individual in-depth interviews were held with the seven experts in a semi-structural manner. The interview data were processed with the approval of the interviewees, who were informed of the data processing method and data confidentiality. The interviews were recorded with a recorder and a notebook on site. After the interviews, the audio data were transcribed. Then, the transcripts were submitted to the interviewees for a review to ensure the accuracy of the data and increase the 
reliability of the research results. For the last step, the data were used for preliminary coding, analysis, and inference.

Regarding the research samples in Phase 2, purposive sampling was applied to invite 17 college teachers of design in Taiwan to complete the questionnaire. The fuzzy Delphi method was used for statistical analysis and was combined with the expert opinions to reach a consensus. All 17 questionnaires were retrieved and valid. All the 17 teachers had obtained an honorary title of "Excellent Teacher", and their teaching was well received. This questionnaire was filled in an anonymous way. All the experts agreed to participate in the survey and allowed the collected data to be used for academic research. The basic information about the teachers is shown in Table 3.

Table 3. Basic Information about the teachers filling the questionnaire based on the fuzzy delphi method.

\begin{tabular}{cccc}
\hline Variable & Category & Number of Valid Samples & $\%$ \\
\hline \multirow{3}{*}{ Years of Service } & $1 \sim 5$ & 4 & $24 \%$ \\
& $6 \sim 10$ & 4 & $24 \%$ \\
& $11 \sim 15$ & 1 & $6 \%$ \\
& $16 \sim 20$ & 2 & $12 \%$ \\
& $21 \sim 25$ & 3 & $18 \%$ \\
& $26 \sim 30$ & 2 & $12 \%$ \\
Position & Over 30 years & 1 & $6 \%$ \\
\hline & Lecturer & 1 & $6 \%$ \\
& Assistant Professor & 7 & $41 \%$ \\
& Associate Professor & 6 & $35 \%$ \\
& Professor & 3 & $18 \%$ \\
\hline
\end{tabular}

\section{Discussion}

\subsection{Results of the Statistical Analysis of the Questionnaire on the Higher Design Education for Sustainable Development}

The United Nations 2030 Sustainable Development Goals (SDGs) is designed to improve people's lives through high-quality education and make it the foundation of sustainable development. To obtain the collective opinion, reach a consensus among the experts, and establish a standard framework, this study designed the items of the expert questionnaire according to the "Elements of Effective Teaching and Activities of Sustainable Development", as based on the results of the expert interviews, which were analyzed by the fuzzy Delphi method (Table 4). The items focused on evaluating the appropriateness and importance of the measurement dimensions, the factors, and the indices. In terms of questionnaire design, the higher design education for sustainable development was divided into seven dimensions: (1) Faith in sustainability in teaching, (2) the trend of talent demand, (3) the teaching value of sustainability, (4) curriculum mapping, (5) teaching approach, (6) teaching evaluation, (7) the sustainable management of teaching development, and 31 indices of evaluating sustainable teaching development. The aim was to explore new educational models and create an environment that fosters both teaching and learning. The questions and statistical results of the questionnaire, as based on the fuzzy Delphi method, are shown in Table 4. Figure 4 reveals the methods and results of the research on design education for sustainable development.

After analysis based on the fuzzy Delphi method, this study defined averages greater than 0.6 to be significant results, while values less than 0.6 were defined to have medium or no significance [42]. In this study, 31 evaluation indexes were established through the interviews, analysis, and inference. After the statistical selection, all these indexes were higher than 0.6. This indicates that they were high in consensus and that the inference was significant and valuable for accelerating the research on teaching. 
Table 4. Results of the questionnaire about effective teaching and activities of higher design education for sustainable development.

\begin{tabular}{|c|c|c|c|}
\hline Dimension & Item & $\begin{array}{c}\text { Index Weight } \\
\text { (Consensus Value) }\end{array}$ & Ranking \\
\hline \multirow{5}{*}{$\begin{array}{l}\text { Faith in Sustainability in } \\
\text { Teaching }\end{array}$} & Train "professional designers" & 0.830 & 2 \\
\hline & $\begin{array}{l}\text { Regard "each student as if he/she was your } \\
\text { child" in teaching }\end{array}$ & 0.600 & 12 \\
\hline & Establish students' "confidence" & 0.700 & 9 \\
\hline & Trigger students' "interest in learning" & 0.830 & 2 \\
\hline & Constantly expand knowledge & 0.840 & 1 \\
\hline \multirow{4}{*}{$\begin{array}{l}\text { The Trend of Talent } \\
\text { Demand }\end{array}$} & For the ability to communicate & 0.811 & 4 \\
\hline & $\begin{array}{l}\text { For "diverse and interdisciplinary" } \\
\text { professionalism }\end{array}$ & 0.802 & 5 \\
\hline & For the "problem-solving" responsibility & 0.821 & 3 \\
\hline & For the "independent thinking" ability & 0.700 & 9 \\
\hline \multirow{5}{*}{$\begin{array}{l}\text { The Teaching Values of } \\
\text { Sustainability }\end{array}$} & $\begin{array}{l}\text { Should help students prepare for } \\
\text { employment and focus on equipping } \\
\text { students with employment skills }\end{array}$ & 0.757 & 8 \\
\hline & $\begin{array}{l}\text { Should pay attention to helping students } \\
\text { put their knowledge into practice }\end{array}$ & 0.775 & 7 \\
\hline & $\begin{array}{l}\text { Should underline the "combination of } \\
\text { enterprises and schools" and narrow the } \\
\text { gap between theory and practice }\end{array}$ & 0.775 & 7 \\
\hline & Should equip students with "creativity" & 0.802 & 5 \\
\hline & $\begin{array}{l}\text { Should focus on the education of } \\
\text { "aesthetics" }\end{array}$ & 0.783 & 6 \\
\hline \multirow{5}{*}{ Curriculum Mapping } & $\begin{array}{l}\text { Should "keep pace with the times" and } \\
\text { change with the times }\end{array}$ & 0.821 & 3 \\
\hline & $\begin{array}{l}\text { Should review the courses of the } \\
\text { department in each semester to determine } \\
\text { which ones can be "connected" }\end{array}$ & 0.775 & 7 \\
\hline & $\begin{array}{l}\text { Should set clear "teaching objectives" for } \\
\text { different courses }\end{array}$ & 0.821 & 3 \\
\hline & $\begin{array}{l}\text { Should have a clear "schedule", set a } \\
\text { weekly theme, inform students of what is to } \\
\text { be taught, how it is taught, and } \\
\text { assignments and assessments }\end{array}$ & 0.700 & 9 \\
\hline & $\begin{array}{l}\text { Should take the "demands of the industry" } \\
\text { into consideration in curriculum mapping }\end{array}$ & 0.614 & 11 \\
\hline \multirow{4}{*}{ Teaching Approach } & $\begin{array}{l}\text { Plan a "design presentation" to offer } \\
\text { students a stage to show their works and } \\
\text { give them a sense of achievement }\end{array}$ & 0.700 & 9 \\
\hline & $\begin{array}{l}\text { Should motivate students to "learn by } \\
\text { doing" to enhance teaching effectiveness }\end{array}$ & 0.821 & 3 \\
\hline & $\begin{array}{l}\text { Adopt "open discussions" when discussing } \\
\text { works with students and encourage them to } \\
\text { make academic progress through } \\
\text { observation }\end{array}$ & 0.811 & 4 \\
\hline & $\begin{array}{l}\text { Combine "courses with competitions" to } \\
\text { sharpen students' professional skills and } \\
\text { increase their competitiveness in } \\
\text { employment }\end{array}$ & 0.700 & 9 \\
\hline
\end{tabular}


Table 4. Cont.

\begin{tabular}{|c|c|c|c|}
\hline Dimension & Item & $\begin{array}{l}\text { Index Weight } \\
\text { (Consensus Value) }\end{array}$ & Ranking \\
\hline \multirow{3}{*}{ Teaching Evaluation } & $\begin{array}{l}\text { Adopt "mutual assessment between peers" } \\
\text { to enable students to assess others and be } \\
\text { assessed, in order to achieve the effects of } \\
\text { cooperative learning }\end{array}$ & 0.632 & 10 \\
\hline & $\begin{array}{l}\text { Use "presentations" to strengthen students' } \\
\text { ability to express themselves }\end{array}$ & 0.700 & 9 \\
\hline & $\begin{array}{l}\text { Employ mutual assessment between peers, } \\
\text { where students score and comment on } \\
\text { works, in order to develop their } \\
\text { "independent" and critical thinking }\end{array}$ & 0.700 & 9 \\
\hline \multirow{5}{*}{$\begin{array}{l}\text { The Sustainable } \\
\text { Management of Teaching } \\
\text { Development }\end{array}$} & $\begin{array}{l}\text { Should review and discuss the course with } \\
\text { students at the end of the course, in order to } \\
\text { "increase teaching effectiveness" }\end{array}$ & 0.783 & 6 \\
\hline & $\begin{array}{l}\text { Should encourage students to participate in } \\
\text { "internships in the industry" to gain early } \\
\text { experience in the workplace and enhance } \\
\text { competitiveness in employment }\end{array}$ & 0.700 & 9 \\
\hline & $\begin{array}{l}\text { "Sustainable design" should emphasize } \\
\text { "humanistic concern" }\end{array}$ & 0.700 & 9 \\
\hline & $\begin{array}{l}\text { The distinctive features of the school should } \\
\text { be prioritized in sustainable operations in } \\
\text { response to the trend of the low birth rate. }\end{array}$ & 0.700 & 9 \\
\hline & $\begin{array}{l}\text { As the low birth rate results in a surplus of } \\
\text { educational resources, the school should } \\
\text { aim to create "exquisite" operations in the } \\
\text { future. }\end{array}$ & 0.700 & 9 \\
\hline
\end{tabular}

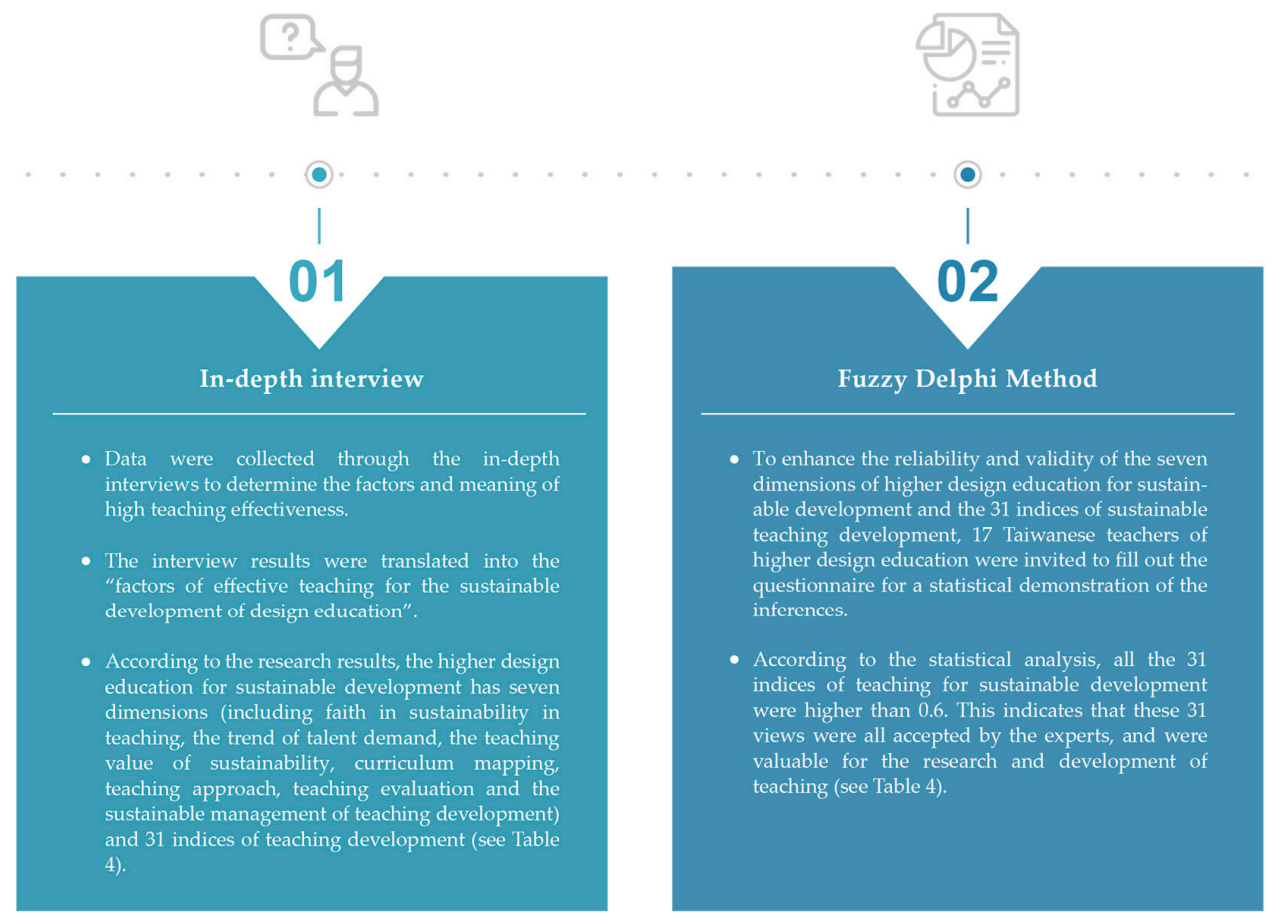

Figure 4. Methods and results of the research on the sustainable development of higher education on design (plotted for this study). 


\subsection{Analysis of the Effective Teaching of Excellent Teachers of Higher Design Education}

Education is the foundation of social development, as well as one of the main topics of the United Nations Sustainable Development Goals (SDGs). As mentioned in Objective 4: It is crucial to ensure the inclusiveness and fairness of education and high-quality education and advocate life-long learning [13]. Hope nurtures each child, and children are our future. Therefore, teachers need to incorporate ESD into the curriculum, and utilize high-quality and sustainable teaching approaches to create a peaceful, fair, and inclusive future. Through statistical analysis of the in-depth interviews and questionnaire, this paper introduces the effective teaching activities of higher design education for sustainable development, as follows:

\subsubsection{The Faith in the Teaching of Higher Design Education for Sustainable Development}

Teachers' faith in teaching has a significant impact on the conduct and quality of teaching. Faith is a weapon for teachers to face challenges in reality [43]. Faith in teaching refers to the knowledge and understanding of a discipline a teacher has, and its definition includes the nature of knowledge, relevant teaching, the theories of children's development, the history of teaching approaches, and social basis [44]. In this study, the key points of faith in teaching for teachers of higher design education are introduced as follows:

1. Higher design education is intended to train professional designers

Cambridge Dictionary defines "profession" as any type of work that requires special training or a particular skill [45].

"Teaching refers to how students are led to acquire something professional." (T1) "Teaching is supposed to be imparting correct and timely expertise and a professional attitude according to the requirements of the industry, it is designed to furnish students with a particular skill." (T3)

Francis Bacon is quoted as saying, "knowledge is power". This study suggests that the department and teachers of higher design education should be aware of the market demands and trends, and plan courses that enrich students' expertise and equip them with professional skills. Moreover, they should help students develop the abilities to find a job and do a good job through learning. The consensus score of the training of professionalism in the expert questionnaire was as high as 0.830 , ranking second place in terms of importance.

2. Regard "each student as if he/she was your child" in teaching

According to education master Froebel, "Education is nothing but a concern for love and role model."

"I regard students as my children in teaching." (T3) "I deem students as my children. I wish the best

for them and would give them whatever they want." (T4)

Teaching is a profession, as well as an ambitious cause. In addition to sharing professional skills, teachers should respect each individual, stand in students' shoes, and communicate with students in a sincere, tolerant, and empathic manner. In learner-centered teaching, teachers are expected to be learning assistants, and offer help to students in their learning at the appropriate time [46]. However, the consensus score of this item in the expert questionnaire was 0.600 , ranking in the last place, which indicates that only a minority of the teachers agreed with this. This study suggests that an appropriate teacher-student relationship should be established to avoid excessive involvement and potentially negative effects.

3. Help students become confident

Confidence is an indispensable factor in one's personal growth, as well as the value of self-assurance. 
"Students will make progress if they feel confident and see their strengths." (T4) "What is taught will enhance students' confidence." (T5)

Hence, teachers should encourage and lead students to become confident and help each of them find what is suitable for him/her. Moreover, teachers should maximize the potential of students, help make them confident, and offer them chances to show their talents.

4. Arouse students' interest in learning

William Butler Yeats mentioned, "Education is not the filling of a pail, but the lighting of a fire."

"Many students don't show interest in learning in class. In this case, their learning effectiveness will not be high. Apart from imparting knowledge, teachers today need to intrigue students' interest in learning." (T5)

Teachers should break away from conventions and explore different teaching models to make lectures interesting and motivate students to study. The most important thing about teaching is to teach in a clear and interesting way [47], and motivation is one of the key factors for successful learning. How to strengthen students' learning motivation is a priority in the development of sustainable education. In addition to improving cognition, emotion, and persistence, being motivated would enable one to be more focused on work and make a greater effort, thus, making tasks easier to complete [48]. Students would find lectures more interesting when there are challenges, meaning if the lecture is too simple, difficult, or boring, students would become distracted. In the future, games and competitions can be introduced into class to offer students a good chance to interact, entertain, and study with each other.

5. Teachers should continuously enrich their knowledge

In the face of social, economic, and technological reforms, teachers must constantly acquire new knowledge to expand their expertise to be a competent teacher.

"I am a school supervisor. Some students often tell me that there is a teacher who uses an outdated textbook in class, which makes them bored." (T5)

A good teacher must be a good learner, and this is especially true with design programs, which always lead the times. Therefore, a teacher should make constant progress and obtain new knowledge to become a life-long learner, in order to be aware of global developments and trends and fulfill the objective of sustainable development through life-long learning [13]. The consensus score of this item in the questionnaire was as high as 0.840 , ranking in first place in terms of expert consensus. Hence, it is highly important.

\subsubsection{The Talent Demand Trends of Relevant Industries in the Future}

Market trends will shape global business models and promote the economy, technological advancement, and market globalization [49]. In this study, the designer demand trend of sustainable development is introduced as follows:

1. The ability to communicate

Communication is a method adopted to fulfill an objective.

"It is an ability to cooperate and communicate with others." (T1). "Communication is not confined to eloquence. It depends on the delivery of professionalism. Clients must be informed through communication. Hence, eloquence and communication skills are equally important." (T4)

Designing requires teamwork, for example, a graphic designer must collaborate with the printing house, a space designer must cooperate with a construction team, a webpage designer must collaborate with a programmer. Therefore, communication plays an essential role in the workplace. One needs 
good communication skills to talk to project leaders, subordinates, colleagues, clients, and business partners, thus, teachers should provide students with many opportunities to express themselves in the form of special topic presentations, design introduction, and mutual assessment between peers.

2. Diverse and interdisciplinary professionalism

In the future, the boundaries among different fields will become blurred, thus, talent must be able to combine the resources of different industries [50].

"A professional designer must be an interdisciplinary talent." (T2) "A designer needs to understand other fields and communicate with other professionals, serving as a bridge of cooperation." (T5) "In the future, design schools will not focus on visual communication or industrial design alone, design should be interdisciplinary." (T6)

This study suggests that design-related talents in the future should be able to combine the knowledge of different industries. In addition to expertise in design, he/she must have the knowledge of other fields, such as the economy, public policy, programming, etc., as such interdisciplinary knowledge will be taken as the foundation for bridging communication gaps. The Medici Effect constantly emphasizes intersection, as the spark ignited by interdisciplinary knowledge will lead to groundbreaking innovation. When entering the intersection of a different industry, subject, or culture, people can incorporate existing ideas to form new ideas [51]. In the future, teachers should integrate diverse cultures into teaching, as the knowledge of diverse cultures can strengthen students' ability to show their creativity and enable them to attain a more remarkable academic record [52]. ESD places emphasis on interdisciplinary knowledge and learners and adopts heuristic, diverse, and democratic teaching strategies to equip students with sustainable development capabilities [53].

\section{Problem-solving responsibility}

The ultimate objective of design is to solve problems, care about society, and create a better life for people.

"A designer must have the abilities to detect and solve problems." (T2) "A designer must have the abilities to detect problems and find effective solutions to them." (T3)

This study suggests that given the rapid social change, we should furnish children with portable competency with which they can explore and acquire new knowledge. The ultimate goal of higher design education should be helping students to prepare for entry into society after graduation and equipping them with life-long learning abilities. According to the results of the Job Outlook 2019 survey, the top three abilities expected by employers are "communication skills (written)", "problem-solving skills", and "the ability to work in a team" [54]. Living in an era of rapid changes and uncertainties, we are confronted with challenges and crises in daily life. Therefore, it is particularly important to develop problem-solving abilities. The consensus score of this item in the expert questionnaire was as high as 0.821 , ranking third in terms of importance.

\section{Independent thinking}

We are living in an Internet era featuring rapid change and the need to distinguish between "true" and "false" in the flow of massive information. In this case, it is highly important to think independently.

"There is no standard for checking the completion of a task. Instead of waiting for a solution when confronted with obstacles, one must develop independent thinking to solve problems." (T3) "At present, it is important to help students become independent and develop independent thinking." (T5)

Independent thinking is an ability most expected from students and in the workplace. Hence, the training of independent thinking should be incorporated into the teaching objectives and courses of higher design education [55]. Teachers can encourage students to consider problems from a different 
perspective in class and guide them to express their ideas with open-ended questions. Moreover, students should be motivated to comment on designs and offer suggestions for improvement. Teachers should encourage students to raise questions to each other and give them chances to solve problems and review their works.

\subsubsection{The Teaching Value of the Sustainable Development of Higher Design Education}

Realizing the value of teaching will give teachers a sense of belonging, a sense of achievement, and motivate them to show greater passion for teaching. In practice, the realization of teaching value must be based on human value. Teachers' pedagogical content knowledge, self-efficacy, and teaching enthusiasm are positively related to students' interest [56]. In this study, the teaching value of the sustainable development of higher design education is introduced as follows:

1. Help students prepare for employment and focus on furnishing them with employment skills

To become competitive in the job market after graduation, the students of higher design education should become clear about their career aspirations, make a career plan, and enrich themselves with necessary professionalism early, in order to be well prepared for job hunting.

"The objective of teaching is to furnish students with employment skills." (T3) "Teaching is oriented by employment. We hope to equip students with what is expected from the workplace." (T5) "The practical experience in the industry is integrated with teaching to help students achieve personal growth and become more competitive in employment." (T7)

Employers expect HEIs to offer the talents that meet the needs of the industry, without providing extra training for the purpose. Hence, it is necessary to arm students with employment skills to make them competitive in the job market [57]. Teachers should adopt "employment-oriented" teaching to help students with their studies.

2. Pay attention to helping students put their knowledge into practice

HEIs are where students are equipped with professionalism, thus, opportunities should be provided to students to put what they learn into practice.

"It's essential to enable students to put what they learn into use, which will give them more possibilities in employment and entrepreneurship." (T6) "In curriculum mapping, we will consider if what is taught in the courses is expected in the workplace after graduation." (T7)

Currently, what is taught at school in Taiwan is not what is expected by enterprises, thus, there is a huge gap between knowledge and practice, and if this problem remains unsolved, the overall industrial and economic development of the country will be affected. In the future, the proportion of enterprise-oriented internships should be enlarged, an enterprise-university cooperation mechanism should be established, experts in the industry should be introduced in class [58]. All such measures will help students put their knowledge into use in the workplace.

3. Underline the "combination of enterprises and schools" and narrow the gap between theory and practice

In the future, exchange and cooperation between schools and enterprises should be strengthened in order that schools are aware of the latest developments in relevant industries and social demands.

"Incorporate enterprise-school cooperation cases into the curriculum, change the traditional enterprise-school cooperation models for better results, encourage students to discuss practical issues, and invite employers to the reviews and presentations of students, as all such measures will give positive feedback to students, and they will become confident." (T5) 
Therefore, the department and teachers of higher design education can invite designers to participate in curriculum mapping to become aware of what is expected in the industry and promote the development and reform of the curriculum. Moreover, some enterprise-school cooperation cases can be incorporated into the curriculum and design practitioners can be invited to mark students' assignments, which will help students understand the basic expertise requirements and developments in the industry, thus, helping them prepare for future employment. Moreover, students' diverse backgrounds and great vitality will inject something fresh into the industry.

4. Equip students with "creativity"

Einstein was quoted as saying, "Imagination is more important than knowledge. Knowledge is limited. Imagination encircles the world." [59]

"What plays an important part in design innovation or creativity is also the ability most underlined in the world." (T1) "It is important to develop students' creative thinking." (T3) "The beginner students may not have superb skills, but they have unbridled creativity. So, I would help them give full play to their creativity." (T5)

Creativity is a treasure that is infinite: Creativity was selected as the most crucial factor for future success [60]. This is also the reason why many organizations are considering the introduction of creative thinking to their organizational cultures, as talents with creative thinking will definitely be popular among enterprises. Experience in diverse cultures can enhance creativity and being exposed to diverse cultures will facilitate creative thinking and contribute to flexible and unique ideas [61]. Therefore, education in creativity based on diverse cultures should be incorporated into the curriculum of higher design education for the publicity of ESD.

5. Focus on education of "aesthetics"

As a sort of competitiveness, aesthetics can improve our life, create an aesthetic economy, and enhance competitiveness. It is not confined to artifacts and can be found in our daily life.

"Education in aesthetics should take root in each place." (T2) "We should review the aesthetics or image composition in graphic design." (T3) "The training of design students should not merely depend on the professors of certain areas or professional skills. Instead, it should be based on the overall training of aesthetical quality." (T6)

The aesthetic literacy of new-generation learners is an important pulse for them in daily life, as it is closely connected with their creativity and life-long learning ability to form competitiveness [62]. Aesthetic literacy is one of the basic civil qualities in countries with an advanced civilization. In particular, design-related professionals must develop their aesthetical professionalism and combine design elements with their career development. In the future, teachers should promote courses of aesthetic creativity and try to take artfulness as the cornerstone of the curriculum, in order that students can enrich their aesthetic literacy from each lecture. In the long-term, aesthetic literacy will become the strongest characteristic of competitiveness for new-generation citizens. [63,64]

\subsubsection{The Curriculum Mapping of the Sustainable Development of Higher Design Education}

Curriculum mapping refers to the process that schools or teachers analyze and plan textbooks, teaching periods, and other necessary resources in a well-organized manner. By making plans and taking preparatory measures before teaching, teachers can learn from each other to achieve effective teaching [65]. In this study, curriculum mapping for the sustainable development of design education is conducted as follows:

1. "Keep pace with the times" and change with the times

What is taught and how it is taught should be appropriately changed according to the times and social demands. 
"We must update at any time and come up with new versions according to the times. We focus on the improvement of the paradigm." "I would change what is taught at any time." (T3) "Teaching needs to be changed according to the times." (T5)

Therefore, teachers need to keep pace with the trend and update what is taught from time to time. In addition, they should make good use of creative teaching to develop teaching contents that meet the needs of the times, develop ideas for life-long learning, and transform students into the talents expected by the future society, thus, what is taught in school should be closely connected with social needs [66]. The consensus score of this item in the expert questionnaire was as high as 0.821 , ranking in third place in terms of importance.

2. Review the department courses of each semester to determine which ones can be "connected"

Vertical consistency should be underlined in different stages of learning. Horizontal integration should be emphasized among different fields (subjects), which will strengthen students' basic learning ability.

"When planning teaching, teachers should not focus on their own courses alone. For instance, I would check all the courses in this semester or this year to see if anyone of them overlaps with mine.

Sometimes, some courses can be connected." (T6)

Hence, teachers' teaching models should not be one-way approach or separated from each other, meaning they should strive to achieve interdisciplinary teaching in a flexible manner. Teachers should be encouraged to form a team to create a co-learning culture, and put forward ideas for mutual assistance, interaction, and putting win-win results into practice, in order to accelerate the sustainable development of teaching.

\section{Set clear "teaching objectives" for different courses}

With an objective in mind, the direction becomes clearer and more focused.

"The first step should be setting objectives for teaching. Then, I will be able to think about the measures to be taken to fulfill these objectives." (T2) "I would set long-term, middle-term and short-term objectives for my teaching and fulfill them in a stepwise manner. Necessary adjustments will be made if there is no objective." (T5)

Teachers should set clear and attainable objectives for each lecture, in order that students will be clear about what they are doing and will do. However, teaching objectives must be built according to the reality of students, and the objectives should be hierarchical and procedural. Hence, teachers should start with small objectives in teaching, and provide students with some challenging but achievable objectives, so that they can have a taste of success. Then, teachers should praise and encourage students at an appropriate time, which will give students confidence and a sense of achievement and urge them to march towards the next objective. The consensus score of this item in the expert questionnaire was as high as 0.821, ranking third in terms of importance.

4. Have a clear "schedule", set a weekly theme, inform students of what is to be taught, and how it is taught, including assignments and the assessments.

Making a schedule for the courses will enable teachers to have effective control over teaching, and students can clearly understand what will be taught, including assignments and assessments, in the coming weeks.

"My course outline is very specific, and each lecture is included in it. The students like my course, because they feel secure and are clear about what they will learn in the six-week course, what they need to learn in each week, and how their academic performance will be evaluated." (T2) 
An effective schedule can help teachers realize their teaching objectives and improve learning, as it works as a tool of communication and management. Moreover, students can select courses according to the course outline or schedule. The teacher-student relationship is not a dominance-obedience one. Teachers should introduce the course outline and schedule at the beginning of a semester and maintain constructive communication with students to reach a consensus and fulfill the objective of the sustainable management of the class.

5. Take the "demands of the industry" into consideration in curriculum mapping

Course design should be based on professionalism and the needs of the industry.

"We provide students with correct and timely expertise and professionalism according to the needs of the industry, with the hope that students would acquire professional skills." (T3) "Students will find a job after graduation. I think it is important to change them into someone that is expected by the industry and society. We hope that what is expected by the industry will be learned by students at school. Otherwise, students would find it hard to hunt for a job, which will result in a new problem." (T5)

According to the abovementioned, schools should invite those from the academic community and the design industry to review and evaluate the courses of different departments, in order to determine whether the courses meet the needs of the market and students. In addition, schools should reinforce the enterprise-school connection, invite designers to teach in class, explore the possibility of interdisciplinary cooperation in course development, encourage students to take off-campus internships, and pay attention to practical and industrial applications to follow the regional development trend of the industry, in order to furnish students with the knowledge and skills expected by the industry and make them more competitive in the job market.

\subsubsection{Teaching Approaches for the Sustainable Development of Higher Design Education}

In the 21st century, teaching is student-centered, and teachers work as learning helpers by offering assistance to students at the appropriate time and situation [46]. Teaching determines the success of teaching and provides important indices regarding education quality. For successful teaching activities, teachers must learn various teaching approaches and strategies, and adopt them to improve students' learning effectiveness, create a positive and enjoyable learning environment, and pursue high-quality teaching featuring sustainable development.

1. Plan a "design presentation" to offer students a stage to show their works and give them a sense of achievement

Through exhibitions and presentations, students can gain experience in self-achievement, which will give them more confidence and a stronger sense of achievement.

"An exhibition will contribute to a strong sense of academic achievement for students." (T2) "Never underestimate the power of putting up or showing designs. You would find that there are some good examples among the designs by students." (T5) "Design exhibitions should be adopted to assess the learning effectiveness of students." (T7)

It is obvious that enhancing students' learning motivation is the main task for teachers to achieve effective teaching. If teachers trigger students' inner motivation by giving them a sense of achievement, students will become concentrated on learning and pursue the perfect result of self-achievement. Winning achievement and honor is the pursuit of the inner mind, and attaining academic achievements and being praised is one of forces that drive students to learn. About $75 \%$ of students gain academic attainments through inner motivation. Satisfaction with life, an optimistic attitude, support from family and society, working state, and age are essential factors that contribute to strong academic motivation [67]. Inherently, everyone desires to be praised. Hence, teachers should give chances to 
students to become successful when teaching, which would give them the motivation to make learning more efficient in the self-affirmation process.

2. Motivate students to "learn by doing" to enhance teaching effectiveness

"Learning by doing" is an educational theory and method proposed by Dewey, which advocates providing students with chances to explore and review through work or activities, so that they will be able to accumulate experience and promote mental development [68].

"Things can be learned by doing." (T5) "To practice the principle of learning by doing, you can give an assignment to students, and ask them to implement a design scheme. Only by witnessing their practice will you be able to see if they have learned anything or met our requirements." (T1) "We should distribute some appropriate tasks among students and ask them to learn by doing. More focus should be placed on practice to allow greater response and feedback among themselves." (T6)

Therefore, teachers should offer students more chances to practice, summarize, analyze, and explore, where they can expand their knowledge and experience and develop the desire to explore and review. This is consistent with the concept of Cone of Learning: Knowledge absorption and retention rate can reach $90 \%$ if students learn through presentation, teaching, simulated experience, and practice [25]. The consensus score of this item in the expert questionnaire was as high as 0.821 , ranking third in terms of importance.

3. Adopt "open discussions" when discussing works with students and encourage them to make academic progress through observations

If a student wants to obtain academic achievement and make progress, he/she should not separate himself/herself from others. Instead, he/she should review and change himself/herself by learning from good models or through open discussions and observations. He/she should absorb what is good in high-quality design and learn a lesson from a poor design.

"Discussions should be taken as the main learning method." (T5) "I don't like one-to-one discussions of designs with students because the mistake by this student may be made by that one. In a group discussion, students can learn from each other, absorb what is good and avoid what is bad. A student would never know the performance of his/her classmates in a one-to-one discussion, which is not good for a positive competition." (T3) "Never underestimate the power of putting up designs. Just display the designs, and you will find that there are some good examples among your students." (T5) "Design stuff is changing all the time. Observation is very important for you if you want to know what to do." (T6)

Discussions and observations can promote interaction between teachers and students, as well as among peers, which leads to effective learning and personal growth. Discussions in class make students the center of learning and an active participant in expanding their knowledge while avoiding acquiring knowledge in a passive manner. Teachers can introduce new concepts by raising relevant questions, and more importantly, open-ended discussions in class will show students how to be an observer, an active listener, and a reactor. Students should be trained to ask, answer, and discuss questions. This is a life-long skill for students [69].

4. Combine "courses with competitions" to sharpen students' professional skills and increase their competitiveness in employment

Competition will lead to progress. Teachers can hold contests for student groups in class to arouse their learning motivation and show them the importance of cooperation in competition.

"There is an assignment in our course. Students can participate in a competition with what they achieve in the assignment, and they are even able to take the competition project as the theme of their 
assignment." "If I think the students are able to do that, I would encourage them to participate in the competition because they will compete with others after graduation in the future. Competition is a good choice for me to train them." (T5)

This study agrees with the abovementioned, as school days are the best time for students to participate in various competitions. Through competitions, they can accumulate practical experience, enrich their professionalism, expand their horizon and put what they learn into practice. Moreover, they can give full play to their talent and expertise, have a clearer idea of their strengths and weaknesses, and make adjustments accordingly. Therefore, teachers should give more chances to students to show themselves and encourage them to take part in various competitions. Students can make progress through competitions, if they win a scholarship or a certificate, it will be a great reward for them. For example, they can invest the scholarship in themselves to become more competitive in the job market and achieve sustainable growth.

\subsubsection{Instructional Evaluation Higher Design Education for Sustainable Development}

Evaluation is a process where information is obtained, and teaching activities are assessed to determine whether they have led to the fulfillment of teaching objectives and enables students to check their academic performance and receive feedback from teachers [70]. The evaluation of higher design education should not be confined to exams. Instead, evaluations should be diversified to avoid the deviations caused by the adoption of a singular assessment [71]. Students should be allowed to participate in as many hands-on activities as possible, such as practice, design making, oral presentations, and exhibitions. Opportunities should be created for students to learn and be evaluated, in order that they would have a sense of academic achievement, and thus, stronger learning motivation.

1. Adopt "mutual assessment between peers" to enable students to assess others and be assessed, in order to achieve the effects of cooperative learning

Mutual assessment by peers means that the learners sharing a similar education level evaluate others and are evaluated by others, enriching their knowledge through observation-based learning.

"According to the questionnaire for the students, they like mutual assessment between peers very much. In the process, students would show high participation, which will contribute to their strong sense of achievement." (T2) "We should offer online and off-line teaching or create a space open to all, where students can make progress together and exchange with each other." (T4)

According to the abovementioned, teachers should create opportunities for collaborative group learning, in order that students would not get separated from each other in learning. Instead, they will be able to collaborate with and assess each other to acquire knowledge. Hence, students should be the center of teaching, while teachers should be a learning assistant who helps students with independent learning. Two main principles should be followed in mutual assessments by peers: (1) The assessment standards should be set in advance, (2) the procedure should be made clear to all the participant students $[72,73]$.

2. Use the "presentation" to strengthen students' ability to express themselves

In modern society, oral expression is an important part of communication, as well as an essential ability that higher design education students should have.

"Young designers are often manipulated by employers due to their poor oral expression ability or lack of confidence." (T3) "For design students, specific value must be conveyed. For instance, the students in our department are required to present their works." (T4) "Presentations should be adopted to enhance students' intention to learn, and they should replace the so-called exams. Only through practice will we be able to see if students have learned what they are expected to acquire." (T5) 
Oral expression ability can be developed, thus, the teachers of higher design education should give students opportunities and space to explore and expand their knowledge with their peers. This will deepen students' understanding of independent learning and make academic progress with feedback from teachers. Students can obtain the following through presentations: (a) The knowledge of the course, (b) the oral expression ability, (c) the independent thinking ability, (d) the ability to control time, (e) how to use learning tools, (f) how to collect and sort information, (g) logic and the ability to organize, (h) the ability to analyze and evaluate, (i) the ability to divide labor and cooperate, (j) the problem-solving ability, (k) the ability to raise good questions, (l) independent learning.

3. Employ mutual assessments by peers, where students must score and comment on works, in order to develop their "independent" and critical thinking

Independent thinking can prevent logical mistakes and lead to rational judgment.

"Interactive assessment of designs is very important. If students participate in it, we will see if they have acquired the knowledge. Students need to do preparatory work if they want to comment on the designs by others." "In mutual assessment between peers, students desire to show their good designs to others. To do so, they need to practice constantly for improvement. Hands represent your skill, while eyes symbolize viewpoint and aesthetic literacy." (T2) "We hope that students will develop the ability of independent thinking to integrate different competencies to solve problems or make something new." (T3)

This study suggests that the mechanism of mutual assessment by peers offers a score, and more importantly, requires the ability to appreciate and evaluate things. For example, a student is expected to develop his/her unique views after attending a lecture or seeing a design piece, rather than making comments alone. Teachers should encourage students to offer well-organized comments regarding a presentation and consider how to make their viewpoints convincing. Comment training is designed to improve students' oral expression and summarization and furnish them with thinking and argument abilities for sustainable development.

\subsubsection{Higher Design Education for Sustainable Development and Management}

Sustainable development is a common social topic in recent years, as well as an important direction for the management and development of higher design education. The Global Action Program (GAP) on Education for Sustainable Development is the follow-up to the United Nations Decade of Education for Sustainable Development after 2014 [2]. Its aim is to apply ESD to provide children with better educational resources and shape distinctive school and curricular features for sustainable development.

1. Teachers should review and discuss the course with students at the end of the course, in order to "increase teaching effectiveness"

Review of teaching means that teachers review their behaviors in teaching, in order to enhance teaching efficacy and promote self-improvement.

"Teaching entails constant adjustment. The contents, approaches, and methodologies of teaching all need to be continuously changed and experimented. Hence, a review is necessary. Students, teachers, and parents all need to review." (T1) "I need someone to give me feedback about my teaching. So, I ask my teaching assistant to observe me and record my teaching. The second method is that we distribute the questionnaire about teaching among students, and this method has been adopted for two years. In the questionnaire, students are expected to express their opinions of me and the course and share their suggestions and expectations. The third one is the focus group, which I think is more effective and simple. The focus group in my class consists of student volunteers, and they are expected to express their views on all items about score ratio and curricular content. As the students are engaged in it, they are active." (T2) "I would adopt rolling teaching, which means that the weekly curricular topic is adjusted according to the competence and performance of students." (T5) 
HEIs aim to integrate reflective learning to enhance self-value and personal courage to face the challenges brought by sustainability in the 21st century [74]. With rapid changes, such as educational reform and flipped classrooms, the traditional teaching model featuring individual teacher's top-down instruction has been changed. If teachers only make one-way contributions and lack stimulation, feedback, and re-education, they would gradually lose their passion for teaching. There are two important time points for reflection: Reflection-in-action (within experience) and reflection-on-action (after experience) [75]. Hence, teachers should carefully observe students' learning, grasp the differences between them, and offer help at the appropriate time in teaching. Moreover, they should engage in reflection and review with students after the course is concluded, and then, make changes to the course according to the feedback from students, which will enable them to increase students' interest in learning and participation, seek sustainable development in their career, and improve their teaching. Flipped education is one of the best ways to improve sustainable education. It is suggested that flipped classes be adopted to achieve reflective teaching and learning in higher design education to increase students' learning effectiveness and create sustainable educational value [76].

2. Encourage students to participate in "internships in the industry", in order to gain early experience in the workplace and enhance their competitiveness in employment.

Through internships, students will acquire professionalism, understand corporate culture, and develop the abilities to finish tasks, solve problems, communicate with others, and coordinate things, thus, creating infinite opportunities and sustainable value for themselves.

"The purpose of teaching is to enable students to put what they learn into practice, and learning, internships, enterprise-school cooperation, and employment are connected. Internships would lead students to employment, which is the most important part of technical education." (T6)

This study suggests that the most important goal for students after graduation is to work. Through internships and job shadowing, students will be able to have an overall understanding of work and become more competitive in the job market. As graduates with professionalism have become increasingly popular in the industry, it is inevitable to combine internships with teaching. Only by taking an internship will students become more active to acquire the knowledge and skills related to their future jobs and be prepared for employment after graduation. Therefore, teachers should encourage students to take an internship and accumulate experience in a real workplace.

3. "Sustainable design" should emphasize "humanistic concern"

Social concern and sustainability are two popular trends in design that attract global attention. They are designed to make life friendlier through design.

"There is a book called Design for the Real World by Victor Papanek, who also authored other two books: Human Scale and The Green Imperative. All these books are about humanism, social design, and green design for developing countries and disadvantaged groups. Hence, designs should be made to care about society and industries. It is important to consider all aspects, especially humanity, in designs." (T1) "We make designs to meet social needs and solve social problems. Now, the Taiwanese economy is not rosy, so recycling old buildings has become the main topic. Another heated issue is senior citizens, which involves indoor obstacle-free facilities." (T4)

In the design of contemporary communities, the discussion has gradually shifted from form and style onto human-centered solutions to problems, i.e., the so-called "design thinking" [77]. The core idea of design will ultimately lie in meeting human demands. Aside from seeking innovation in vision, material, structure, and function, design is a carrier of feeling, a way to express ideas, a thought of human, life, and environment, as such designs bring warmth. The English word "design" means "to give significance" in Latin. The biggest difference between design and art is that design is functional and plays an important role in the sustainable management of the Earth [78]. Therefore, future designs 
should be human-oriented and focus on demands and solutions. As there is only one Earth in the universe, all citizens of the global village should be friendly to the environment and care about the Earth. In particular, designers should be aware of human demands and give full play to designs to make the world a better place and create a sustainable future.

4. The distinctive features of a school should be prioritized in its sustainable operations in response to the trend of a low birth rate.

Education takes an essential place in a country's 100-year plan of development, and school education is part of sustainable management. In the face of fierce global competition and the problem of a low birth rate, seeking diversity and innovation has become an important development trend in educational reform.

"The predicament we face today has been prompted by a large number of universities." (T1) "For me, a low birth rate is good for Taiwanese education to some extent, because it will lead to smaller classes. Therefore, the government should not take education as a profit-earning tool, but welfare for society."

(T2) "I think distinctive development is important. If you have distinctive features, you would face fewer impacts of a low birth rate. By the way, I would recommend the so-called transformative exquisite courses." (T5)

School is the carrier of education, as well as an important experiment site where the idea of sustainable development is put into practice. On campuses of higher education, sustainable development can be promoted to open effective ways of creating a sustainable future [79]. We have entered the era of an innovation economy in the 21st century. Schools' innovative management is not a slogan, but a practical attitude and action. Schools should show their distinctive courses and ceaselessly pursue excellence and innovation. For distinctive development, the first step is to explore and examine resources, know the strengths and weaknesses of the organization, and improve the special courses of sustainable development. By doing so, we will be able to make schools into reliable and popular sites for education and fulfill the objective of sustainable management.

5. As a low birth rate results in a surplus of educational resources, schools should aim to create "exquisite" operations in the future.

University shoulders the social responsibility of spreading knowledge and training talents and serves as the best practical platform for fulfilling the objective of sustainable education. In addition, it can be committed to the achievement of Sustainable Development Goals (SDGs) and contribute to fair, inclusive, and high-quality education [80].

"I would recommend the so-called transformative exquisite courses. This means that I would adopt different teaching approaches according to the size of the class. As for 'exquisite', it is important and I think the courses can be adjusted for it." (T5)

All well-organized things or activities are exquisite to some degree, thus, high-quality and exquisite education is the concept that we should advocate and persist in. It is hoped that school operators and teachers will provide safe campuses and classrooms, as well as complete and adequate educational facilities and equipment for students, assist students in independent learning, offer high-quality and exquisite courses and teaching, and enrich students' knowledge. Moreover, they should organize colorful campus activities, furnish students with humanistic attainments, endeavor to build a high-quality smart campus, and contribute to the sustainability of an exquisite campus.

\section{Conclusions}

This study adopted qualitative and quantitative methods to probe into the factors and meanings of high-quality teaching by twelve college teachers. In addition, the fuzzy Delphi method was utilized to collect the opinions of the experts to reach a consensus and establish the standards. The teachers' 
teaching models were special, and the following conclusions have been drawn according to the research results:

(1). The sustainable high-quality teaching efficacy of higher design education teachers can be divided into seven categories, as follows: (a) Faith in sustainability in teaching, (b) the trend of talent demand, (c) the teaching value of sustainability, (d) curriculum mapping, (e) teaching approach, (f) teaching evaluation, (g) the sustainable management of teaching development.

(2). According to the analysis of the factors of high-quality teaching, teaching situations, and viewpoints of higher design education teachers, the teachers have a strong passion for teaching and care about their students. They focused on equipping the design students with independent learning abilities and advocated changing teacher-centered teaching into student-centered teaching. They adopted diverse teaching models to enhance students' interest in learning and furnished students with professionalism and confidence. Emphasis was placed on learning by doing, and priority was given to the connection between higher education and enterprise-school cooperation to reinforce students' competitiveness in the future job market. In teaching, teachers carefully observed the students' reactions and made appropriate adjustments and changes. Moreover, they reviewed teaching after class to make future teaching or activities more efficient and endeavored to realize the value of ESD.

(3). Regarding the high-quality teaching and teachers of higher design education for sustainable development, this study proposes the following suggestions: (a) Establish a professional learning community (PLC) to increase the professionalism of teachers and improve teaching through cooperation, (b) observe or learn from excellent teachers, with focus on how they teach and motivate students, (c) closely follow the times and the industry, as design is an industry that leads fashion, (d) teachers should incorporate work ethic into courses to make students aware that they must observe the rules, regulations, and ethics in the workplace, and construct a peaceful, fair, and inclusive world of sustainable development.

Author Contributions: Y.-C.L. contributed to the conceptual design of the study, data collection, drafting of the article, and passed through to the final approval. L.-H.P. contributed to the conceptual design of the study, supervision of the progress, and guided to the final approval. All authors have read and agreed to the published version of the manuscript.

Funding: This research received no external funding.

Acknowledgments: The authors would like to thank the editors and anonymous reviewers for their constructive comments and valuable suggestions to improve the paper. Also, sincere thanks for all interviewees for sharing their valuable experiences and contributions to this research.

Conflicts of Interest: The authors declare no conflicts of interest.

\section{References}

1. UNESCO. Education for Sustainable Development: Sourcebook; UNESCO: Paris, France, 2012; Available online: https://sustainabledevelopment.un.org/content/documents/926unesco9.pdf (accessed on 1 October 2019).

2. UNESCO. Education for Sustainable Development Goals: Learning Objectives; UNESCO: Paris, France, 2017; Available online: https://unesdoc.unesco.org/ark:/48223/pf0000247444 (accessed on 1 October 2019).

3. UNESCO. Shaping the Future We Want: UN Decade of Education for Sustainable Development (2005-2014); UNESCO: Paris, France, 2014; Available online: https:/unesdoc.unesco.org/ark:/48223/pf0000230171 (accessed on 1 October 2019).

4. UNESCO. Global Action Programme on Education for Sustainable Development. Available online: https: //en.unesco.org/gap (accessed on 1 October 2019).

5. Martin, S.; Martin, M.; Jucker, R.; Roberts, C. Education and Sustainable Development_Learning to Last? In Innovation in Education; Larkley, J.E., Maynhard, V.B., Eds.; Nova Science Publishers, Inc.: Hauppauge, NY, USA, 2008; pp. 51-92.

6. Wright, T.S.A. Definitions and frameworks for environmental sustainability in Higher Education. Int. J. Sustain. High. Educ. 2002, 3, 203-220. [CrossRef] 
7. Cebrián, G.; Junyent, M. Competencies in Education for Sustainable Development: Exploring the Student Teachers' Views. Sustainability 2015, 7, 2768-2786. [CrossRef]

8. International Design Competition (IDC). Plot Twists and Turns of Design. Available online: https://www.moe-idc.org/node/494?fbclid= IwAR0JHkOORqKHZqpQtFNbnJK2RDtVzFcUm5mzdPdoDCphzqT2DykvudL16Lk (accessed on 21 November 2019).

9. Tu, J.C.; Liu, L.X.; Wu, K.Y. Study on the Learning Effectiveness of Stanford Design Thinking in Integrated Design Education. Available online: https://ideas.repec.org/a/gam/jsusta/v10y2018i8p2649-d160423.html (accessed on 10 December 2019).

10. Varouchas, E.; Sicilia, M.Á.; Sánchez-Alonso, S. Academics' Perceptions on Quality in Higher Education Shaping Key Performance Indicators. Available online: https://www.researchgate.net/publication/329647979_ Academics'_Perceptions_on_Quality_in_Higher_Education_Shaping_Key_Performance_Indicators (accessed on 10 December 2019).

11. Thomas, I. Special Issue-Pedagogy for Education for Sustainability in Higher Education. Sustainability 2014, 6, 1705-1708. [CrossRef]

12. Quacquarelli Symonds. Sustainability in Higher Education: What More Can Universities Do? 2019. Available online: http://info.qs.com/rs/335-VIN-535/images/Sustainability-in-HE-What-More-Can-Universities-Do. pdf (accessed on 5 October 2019).

13. United Nations. Transforming Our World: The 2030 Agenda for Sustainable Development. Available online: https://sustainabledevelopment.un.org/post2015/transformingourworld (accessed on 5 October 2019).

14. UNESCO. Issues and Trends in Education for Sustainable Development. 2018. Available online: https: //unesdoc.unesco.org/ark:/48223/pf0000261445 (accessed on 1 October 2019).

15. Goritz, A.; Kolleck, N.; Jörgens, H. Education for Sustainable Development and Climate Change Education: The Potential of Social Network Analysis Based on Twitter Data. Available online: https://www.researchgate.net/publication/336268847_Education_for_Sustainable_Development_and_ Climate_Change_Education_The_Potential_of_Social_Network_Analysis_Based_on_Twitter_Data (accessed on 10 December 2019).

16. UNESCO. Education for Sustainable Development. Available online: https://en.unesco.org/themes/educationsustainable-development (accessed on 1 October 2019).

17. Mochizuki, Y.; Fadeeva, Z. Competences for Sustainable Development and Sustainability: Significance and Challenges for ESD. Int. J. Sustain. High. Educ. 2010, 11, 391-403. [CrossRef]

18. Sipos, Y.; Battisti, B.; Grimm, K. Achieving Transformative Sustainability Learning: Engaging Head, Hands and Heart. Int. J. Sustain. High. Educ. 2008, 9, 68-86. [CrossRef]

19. Svanström, M.; Lozano-García, F.; Rowe, D. Learning Outcomes for Sustainable Development in Higher Education. Int. J. Sustain. High. Educ. 2008, 9, 339-351. [CrossRef]

20. Weik, A.; Withycombe, L.; Redman, C.L. Key competencies in sustainability: A reference framework for academic program development. Sustain. Sci. 2011, 6, 203-218. [CrossRef]

21. Wals, A.E.J. Mirroring, Gestaltswitching and Transformative Social Learning: Stepping Stones for Developing Sustainability Competence. Int. J. Sustain. High. Educ. 2010, 11, 380-390. [CrossRef]

22. Oxford Dictionary. Teach. Available online: https://www.lexico.com/en/definition/teach (accessed on 5 October 2019).

23. Coe, R.; Aloisi, C.; Higgins, S.; Major, L. What Makes Great Teaching? 2014. Available online: https: //www.suttontrust.com/wp-content/uploads/2014/10/What-Makes-Great-Teaching-REPORT.pdf (accessed on 5 October 2019).

24. Berk, R.A. Survey of 12 Strategies to Measure Teaching Effectiveness. Int. J. Teach. Learn. High. Educ. 2005, $17,48-62$.

25. Dale, E. Audio-Visual Methods in Teaching; Holt, Rinehart and Winston: New York, NY, USA, 1998.

26. Brito, R.M.; Rodríguez, C.; Aparicio, J.L. Sustainability in Teaching: An Evaluation of University Teachers and Students. Sustainability 2018, 10, 439. [CrossRef]

27. Fadeeva, Z.; Mochizuki, Y. Higher Education for Today and Tomorrow: University Appraisal for Diversity, Innovation and Change towards Sustainable Development. Sustain. Sci. 2010, 5, 249-256. [CrossRef]

28. UNESCO. Education for Sustainable; UNESCO: Paris, France, 2002. Available online: https://www.mma.gov. br/estruturas/educamb/_arquivos/20_11122008091834.pdf (accessed on 6 October 2019). 
29. EU-USR. Social Responsibility of Universities in Europe and Development of a Community Reference Framework. 2018. Available online: http://www.eu-usr.eu/wp-content/uploads/2014/05/2013_EU-USR_eleaflet.pdf (accessed on 7 October 2019).

30. Brown, T.; Katz, B. Change by Design. J. Prod. Innov. Manag. 2011, 28, 381-383. [CrossRef]

31. Lozano, R.; Barreiro-Gen, M.; Lozano, F.J.; Sammalisto, K. Teaching Sustainability in European Higher Education Institutions: Assessing the Connections between Competences and Pedagogical Approaches. Available online: https://www.researchgate.net/publication/331813181_Teaching_Sustainability_in_ European_Higher_Education_Institutions_Assessing_the_Connections_between_Competences_and_ Pedagogical_Approaches (accessed on 10 December 2019).

32. Hamiti, S.W.; Wydler, H. Supporting the Integration of Sustainability into Higher Education Curricula-A Case Study from Switzerland. Sustainability 2014, 6, 3291-3300. [CrossRef]

33. Center for Taiwan Academic Research Ethics Education. Available online: https://ethics.moe.edu.tw/intro/ (accessed on 10 December 2019).

34. World Medical Association. World Medical Association Declaration of Helsinki. Bull. World Health Organ. 2001, 79, 373.

35. World Health Organization. The Declaration of Helsinki and Public Health. Available online: https: //www.who.int/bulletin/volumes/86/8/08-050955/en/ (accessed on 10 December 2019).

36. Boyce, C.; Neale, P. Conducting In-Depth Interviews: A Guide for Designing and Conducting In-Depth Interviews for Evaluation Input. 2006. Available online: http://www2.pathfinder.org/site/DocServer/m_e_ tool_series_indepth_interviews.pdf (accessed on 8 October 2019).

37. Chang, S.H. Fuzzy Multi-Criteria Decision Making for Evaluation Method; Wu-Nan Book: Taipei, Taiwan, 2012.

38. RAND Corporation. Delphi Method. Available online: https://www.rand.org/topics/delphi-method.html (accessed on 10 October 2019).

39. IGI-Global. What is Fuzzy Delphi Method. Available online: https://www.igi-global.com/dictionary/ demystifying-the-delphi-method/44876 (accessed on 10 October 2019).

40. Ishikawa, A.; Amagasa, M.; Shiga, T.; Tomizawa, G.; Tatsuta, R.; Mieno, H. The Max-Min Delphi Method and Fuzzy Delphi Method via Fuzzy Integration. Fuzzy Sets Syst. 1993, 55, 241-253. [CrossRef]

41. Aliev, R.; Aliev, R.R.; Ahmedov, I.Z.; Aliyeva, K.R.A. Fuzzy Delphi Method. J. Knowl. 2004, 1, 3-4.

42. Soofi, A.S.; Goodarzi, M. The Development of Science and Technology in Iran: Policies and Learning Frameworks; Palgrave Macmillan: London, UK, 2017.

43. Mayer, R. Recent Research on Teacher Beliefs and Its Use in the Improvement of Instruction. In Proceedings of the Annual Meeting of the American Educational Research Association, Chicago, IL, USA, 31 March-4 April 1985; p. 28.

44. O'Loughlin, M. The Influence of Teachers' Beliefs about Knowledge, Teaching, and Learning on Their Pedagogy: A Constructivist Reconceptualization and Research Agenda for Teacher Education. In Proceedings of the Annual Symposium of the Jean Piaget Society, Philadelphia, PA, USA, June 1989; pp. 1-25, (ERIC Reports 339679). Available online: https://eric.ed.gov/?id=ED339679 (accessed on 15 October 2019).

45. Cambridge Dictionary. Available online: https://dictionary.cambridge.org/zht/ (accessed on 16 October 2019).

46. Herranen, J.; Vesterinen, V.M.; Aksela, M. From Learner-Centered to Learner-Driven Sustainability Education. Available online: https://www.mendeley.com/catalogue/learnercentered-learnerdrivensustainability-education/ (accessed on 10 December 2019).

47. Social Enterprise Insights. Interview with Ping-Cheng Yeh: A Teacher's Life-long Objective Is to Motivate Students to Learn. Available online: https://www.seinsights.asia/article/3290/3273/5432 (accessed on 21 October 2019).

48. Hidi, S. Interest, reading, and learning: Theoretical and practical consideration. Educ. Psychol. Rev. 2001, 13, 191-209. [CrossRef]

49. Oxford Economics. Global Talent 2021. Available online: https://www.oxfordeconomics.com/Media/Default/ Thought\%20Leadership/global-talent-2021.pdf (accessed on 17 October 2019).

50. Ross, A. The Industries of the Future; Simon \& Schuster: New York, NY, USA, 2016.

51. Johansson, F. The Medici Effect: What Elephants and Epidemics Can Teach Us About Innovation; Harvard Business School Press: Boston, MA, USA, 2004.

52. Chang, J.; Su, J.C.; Chen, H. Rethinking the Multicultural Experiences-Creativity Link. In The Cambridge Handbook of Creativity and Personality Research; Cambridge University Press: Cambridge, UK, 2017; pp. 124-139. 
53. Pauw, J.B.; Gericke, N.; Olsson, D.; Berglund, T. The Effectiveness of Education for Sustainable Development. Sustainability 2015, 7, 15693-15717. [CrossRef]

54. National Association of Colleges and Employers (NACA). Job Outlook 2019. Available online: https: //www.odu.edu/content/dam/odu/offices/cmc/docs/nace/2019-nace-job-outlook-survey.pdf (accessed on 17 October 2019).

55. Bezanilla, M.J.; Fernández-Nogueira, D.; Poblete, M.; Galindo-Domínguez, H. Methodologies for Teaching-Learning Critical Thinking in Higher Education: The Teacher's View. Think. Ski. Creat. 2019, 33, 100584. [CrossRef]

56. Fauth, B.; Decristan, J.; Decker, A.-T.; Büttner, G.; Hardy, I.; Klieme, E.; Kunter, M. The Effects of Teacher Competence on Student Outcomes in Elementary Science Education: The Mediating Role of Teaching Quality. Teach. Teach. Educ. 2019, 86, 102882. [CrossRef]

57. Husain, M.Y.; Mokhtar, S.B.; Ahmad, A.A.; Mustapha, R. Importance of Employability Skills from Employers' Perspective. Procedia Soc. Behav. Sci. 2010, 7, 430-438. [CrossRef]

58. Chen, C.L. How to Narrow the Gap between Theory and Practice. Available online: https://www.npf.org.tw/ 1/17982 (accessed on 17 October 2019).

59. Einstein, A. What Life Means to Einstein. Available online: https://archive.org/details/ WhatLifeMeansToEinstein_201712 (accessed on 23 October 2019).

60. IBM 2010 Global CEO Study: Creativity Selected as Most Crucial Factor for Future Success. Available online: https://www-03.ibm.com/press/us/en/pressrelease/31670.wss (accessed on 18 October 2019).

61. Sharif, R. The Relations between Acculturation and Creativity and Innovation in Higher Education: A Systematic Literature Review. Educ. Res. Rev. 2019, 28, 100287. [CrossRef]

62. Gallagher, M.S.; Ihanainen, P. Aesthetic Literacy: Observable Phenomena and Pedagogical Applications for Mobile Lifelong Learning (MLLL). Eur. J. Open Distance E-Learn. 2015, 18, 15-33. [CrossRef]

63. Chemi, T. The Teaching Artist as Cultural Learning Entrepreneur: An Introductory Conceptualization. Teach. Artist J. 2015, 13, 84-94. [CrossRef]

64. Chao, H.L. Gather Beauty and Combine Art: The Theory and Practice of Interdisciplinary Courses on Aesthetics; Ainosco Press: New Taipei City, Taiwan, 2016.

65. Chou, S.C. Curriculum Mapping. Available online: http://terms.naer.edu.tw/detail/1314072/ (accessed on 18 October 2019).

66. Dewey, J. The School and Society: Being Three Lectures; University of Chicago Press: Chicago, IL, USA, 1899.

67. Hamdan-Mansour, A.M.; Hamaideh, S.H.; Azzeghaiby, S.N.; Hanouneh, S.I.; Aboshaiqah, A.E. Psychosocial Correlates of Motivation for Academic Accomplishment among University Students. Open J. Med. Psychol. 2015, 4, 1-8. [CrossRef]

68. Dewey, J. The Bearings of Pragmatism Upon Education. In The Middle Works of John Dewey; Boydston, J.A., Ed.; Southern Illinois University Press: Carbondale and Edwardsville, IL, USA, 1908; Volume 4, pp. 178-191.

69. Shih, M.Y. How to Guide Students to Learn with Questions (Class Discussion). Eval. Bimon. 2013, 41, 29-30.

70. Taut, S.; Rakoczy, K. Observing Instructional Quality in the Context of School Evaluation. Learn. Instr. 2016, 46, 45-60. [CrossRef]

71. Butler, A.C. Multiple-Choice Testing in Education: Are the Best Practices for Assessment Also Good for Learning? J. Appl. Res. Mem. Cogn. 2018, 7, 323-331. [CrossRef]

72. Seger, M.; Dochy, F. New Assessment Forms in Problem-based Learning: The value-added of the students' perspective. Stud. High. Educ. 2001, 26, 327-343. [CrossRef]

73. Chang, C.H.; Tsai, M.H. Suggestions on the Principles and Practice of Mutual Assessment of Assignments between Peers. Taiwan Educ. Rev. Mon. 2018, 7, 212-218.

74. Díaz-Iso, A.; Eizaguirre, A.; García-Olalla, A. Extracurricular Activities in Higher Education and the Promotion of Reflective Learning for Sustainability. Available online: https: //www.researchgate.net/publication/335317044_Extracurricular_Activities_in_Higher_Education_ and_the_Promotion_of_Reflective_Learning_for_Sustainability (accessed on 10 December 2019).

75. Schön, D.A. The Reflective Practitioner: How Professionals Think in Action; Basic Books: New York, NY, USA, 1983. 
76. Buil-Fabregá, M.; Martínez Casanovas, M.; Ruiz-Munzón, N.; Filho, W.L. Flipped Classroom as an Active Learning Methodology in Sustainable Development Curricula. Available online: https://www.researchgate.net/publication/335399659_Flipped_Classroom_as_an_Active_Learning Methodology_in_Sustainable_Development_Curricula (accessed on 10 December 2019).

77. Taiwan Design Center. Design should be Based on Humanistic Concern. Explore the Modern Spirit of the Chinese Culture and Ideology_He-Shuo Fan. Available online: https://www.tdc.org.tw/17271 (accessed on 21 October 2019).

78. TechOrange. What is a "Good Design"? Be Aware of Demands and Solve Problems: A Good Design Can Change the World. Available online: https://buzzorange.com/techorange/2018/09/13/what-is-good-design/ (accessed on 21 October 2019).

79. Sun, C.J.; Chiou, S.C. The Comparison of Campus Planning Development at the Initial Stage of School Establishment: A Study of the Two Newly Instituted Private Universities of Science and Technology in Taiwan. Sustainability 2019, 11, 1525. [CrossRef]

80. UNITED NATIONS. About the Sustainable Development Goals. Available online: https://www.un.org/ sustainabledevelopment/sustainable-development-goals/ (accessed on 21 October 2019).

(C) 2019 by the authors. Licensee MDPI, Basel, Switzerland. This article is an open access article distributed under the terms and conditions of the Creative Commons Attribution (CC BY) license (http://creativecommons.org/licenses/by/4.0/). 